\section{Time and Power in the European Commission}

\author{
Klaus H. Goetz
}

LMU Munich
International Review of Administrative Sciences 2014, Vol. 80(3) 577-596

(C) The Author(s) 2014

Reprints and permissions: sagepub.co.uk/journalsPermissions.nav DOI: $10.1177 / 00208523 \mid 4543436$ ras.sagepub.com

\begin{abstract}
Major recent studies of the European Commission have emphasised the growing politicisation and centralisation as important trends transforming its organisation. The present article analyses the role that time rules and temporal practices that structure the operation of the Commission have played in these trends. It finds a clear temporal subtext to politicisation and centralisation. This becomes evident when one examines two key time-sensitive relationships: between the political level - the College of Commissioners - and the administrative level; and between central coordination units - notably the Secretariat-General - and line units. Political time-setting, monitoring and enforcement have assumed greater prominence, reducing the temporal discretion of the administration; central 'keepers of the clock' have acquired greater power; and traditional bureaucratic advantages in time budgets and time horizons have diminished.
\end{abstract}

\title{
Keywords
}

European Union, administrative organization and structures, international organizations (IGOs), public Administration

\section{Time and the Changing Nature of the European Commission}

Although 'time' has long been an important theme in sociological organisational analysis (Simsa 1996) and in the organisational management literature (Bluedorn and Denhardt 1988; Ancona et al. 2001), the temporality of public administration has rarely been the focus of empirical analysis and its linkages to power have not been explored in a systematic fashion. Administrations institutionalise time primarily in the form of rules that determine the tenures of office holders; through budgetary, planning, decision-making and implementation rules that determine when, in what order, how quickly and for how long actions can be taken; and

\section{Corresponding author:}

Klaus Goetz, Ludwig-Maximilians-Universität (LMU) München, Oettingenstraße 67, München, 80538, Germany.

Email: goetz.Imu@gmail.com 
through timetables and schedules with their mobilising, prioritising and deadlining effects. In addition to formal time rules, administrations operate on the basis of more or less deeply entrenched informal temporal practices.

The manner in which time is arranged matters for the distribution of power within the administration. It is generally acknowledged that actors' control over time is an important source of power within organisations (Simsa 1996), expressed, in particular, through differentials in actors' available time budgets and their time horizons; their authority to set, monitor and enforce the clock for others; and the temporal discretion they enjoy in their own actions. The distinction between organisational 'time-setters' and 'time-takers' is fundamental in this respect, and attempts to exercise power by timetable, i.e. by imposing one's own temporal preferences on others, notably through deadlining, are commonplace (Luhmann 1971). Yet, empirical studies of administrative time are rare (Ekengren, 1996, 2002; see Pollitt 2008 for a review).

Against this background, the following discussion seeks to shed some light on how time is institutionalised in the European Commission and how this matters for the distribution of power. In so doing, it engages with, and seeks to contribute to, two hitherto largely unconnected debates: the first, already referred to, on how time matters for power in organisations; and the second, on the changing nature of the European Commission. Recent major in-depth studies of the European Commission have highlighted two key interconnected trends: politicisation and centralisation. As regards the former, Wille (2013) shows how Commissioners on the one hand, and senior officials on the other, have become increasingly distinct in their tasks and outlook: Commissioners have evolved from 'technocrats to politicians' and senior officials from 'mandarins to managers'. The result is, according to Wille, an 'emerging political-administrative dichotomy', in which respective roles are clearly separated and in which political controls over the administration are strengthened.

The study by Kassim et al. (2013) demonstrates how attempts at greater control over the administration by the College of Commissioners and, in particular, the Commission President, have furthered centralisation within the organisation. Thus, under the Presidency of Barroso (2004 to 2014), 'The degree to which the leadership has been centralized around the person of the Commission President is remarkable' (Kassim et al. 2013: 282). In what is identified as a 'presidential leadership model', 'Barroso, together with the Secretary General, Catherine Day, has transformed the Secretariat-General from a service that supports the College to a service of the Commission President, and has supported a more interventionist role for the Secretariat-General in policy-making' (ibid.: 282.). As part of these trends, the scope for 'bureaucratic entrepreneurs', notably heads of unit, has been significantly curtailed, not least since 'crucial individuals have less time for policy content than they used to have in the past' (Bauer 2008: 703).

The following analysis shows that there has been strong temporal subtext to these developments. Special attention is paid to two time-sensitive relationships. The first concerns administrative autonomy: How autonomous from the political 
level is the administration in setting its clocks? The second relates to organisational centralisation and differentiation: What is the relationship between central coordination units, notably the Secretariat-General of the European Commission, and line units in determining organisational clocks? The article also considers changes in actors' time budgets and time horizons. The argument advanced is that we witness a gradual decline in the temporal discretion of the administration and a gradual increase in central time-setting.

Before turning to the empirical discussion, it is worth setting out briefly the understanding of the relationship between the institutionalisation of time and its link to power that informs this article. In line with the central assumptions of actorcentred institutionalism (Scharpf 1997), time rules and temporal practices are understood as part of a 'a system of rules that structure the courses of actions that a set of actors may chose', and these rules may be formal or consist of 'social norms that actors will generally respect and whose violation will be sanctioned by loss of reputation, social disapproval, withdrawal of cooperation and rewards, or even ostracism' (Scharpf 1997: 38). Accusations of 'bad timing', 'undue haste' or 'playing for time' often result from perceived violations of such social norms. Importantly, institutions so understood 'define repertoires of more or less acceptable courses of action that will leave considerable scope for the strategic and tactical choices of purposeful actors' (ibid.: 42).

Understanding time as part of the institutional makeup of the Commission, the following analysis proceeds on the basis of three basic explanatory assumptions as regards the connection between institutionalised time and the power of actors. These assumptions draw on the insights of actor-centred institutionalism; decision-making analysis, which highlights the linkages between temporal discretion and the capacity for substantive goal attainment (Pollitt 2008); and sociological accounts of time and organisations, which stress the importance of organisational hierarchies and differential 'time ownership' (Simsa 1996). First, actors with bigger time budgets, notably longer terms of office, and more extended future time horizons are privileged vis-à-vis those who have shorter periods of office and fewer incentives or opportunities for taking the 'longer view'; second, the greater actors' temporal discretion, the greater their chances of realising their own substantive objectives; third, the greater actors' capacity to impose their temporal preferences on others, the greater, again, the likelihood that they can realise their substantive objectives.

Although the focus of the present discussion is on temporal rules and practices and their implications for the distribution of power, it should be noted that like other rules, they rarely matter in isolation. For example, time-related decisionmaking rules typically interact with substantive competences, and the power implications of an actor's ability to establish a binding timetable can only be fully understood if temporal and substantive discretion are considered in conjunction. This need to put time into context also implies that it would be misleading to consider changes in time rules and practices either exclusively as drivers of politicisation and centralisation or, conversely, solely as expressions of changing power 
relations. Rather, by foregrounding time as a neglected dimension of the institutionalisation of the Commission, the present analysis is able to show how organisational trends are both shaped by, and reflected in, changing temporal frameworks.

\section{The Commission Timescape: Time Rules and Practices}

If we attempt to sketch the contours of the Commission's timescape, it makes sense to start by examining time rules at the levels of the Treaties, the Commission's Rules of Procedure and 'Implementing Rules', giving effect to the Rules of Procedure. In so doing, one needs to pay attention both to rules that refer exclusively to the inner workings of the Commission, but also to time rules that govern the relationship between the Commission and others, notably the Council and the European Parliament, for these, too, have implications for the intra-organisational distribution of powers. Table 1 lists the main rules and offers a brief substantive description.

Table I. Time Rules Relating to the European Commission

\begin{tabular}{|c|c|c|}
\hline Content of Rule & Time Rule & Article \\
\hline \multicolumn{3}{|l|}{ a) In the Treaties } \\
\hline Term length & Duration & $\begin{array}{l}\text { TEU } \S I 7 / 3 \\
\text { (new in TEU) }\end{array}$ \\
\hline Members' nomination & Sequence & $\begin{array}{l}\text { TEU } \S \mid 7 / 7 \\
\text { (ex TEC } 2 \mid 4 / 2)\end{array}$ \\
\hline Review of state aids & Sequence, Duration & $\begin{array}{l}\text { TFEU §I } 08 \\
\text { (ex TEC §88) }\end{array}$ \\
\hline $\begin{array}{l}\text { Monitor of member states' } \\
\text { budgets }\end{array}$ & Sequence, Duration & $\begin{array}{l}\text { TFEU } § 126 \\
(\text { ex TEC } § 104)\end{array}$ \\
\hline $\begin{array}{l}\text { Consultation of labour and } \\
\text { management }\end{array}$ & Sequence, Duration & $\begin{array}{l}\text { TFEU §I } 54 \\
(\mathrm{ex} \text { TEC } § \mid 38)\end{array}$ \\
\hline $\begin{array}{l}\text { Internal allocation of } \\
\text { responsibilities }\end{array}$ & Timing & $\begin{array}{l}\text { TFEU } § 248 \\
\text { (ex TEC } \S 217 / 2)\end{array}$ \\
\hline $\begin{array}{l}\text { General report on the activities } \\
\text { of Union }\end{array}$ & Regularity, Timing & $\begin{array}{l}\text { TFEU } \S 249 / 2 \\
(\mathrm{ex} \mathrm{TEC} \S 2 / 2)\end{array}$ \\
\hline $\begin{array}{l}\text { Member state (MS) breaking the } \\
\text { Treaties }\end{array}$ & Duration & $\begin{array}{l}\text { TFEU } \S 258 \\
(\mathrm{ex} \text { TEC } \S 226)\end{array}$ \\
\hline $\begin{array}{l}\text { MS accused of Treaty breaking by } \\
\text { other MS }\end{array}$ & Sequence, Duration & $\begin{array}{l}\text { TFEU } § 259 \\
\text { (ex TEC } § 227)\end{array}$ \\
\hline $\begin{array}{l}\text { The time a MS has to comply to } \\
\text { EC] ruling }\end{array}$ & Duration & $\begin{array}{l}\text { TFEU } \S 260 / 2 \\
(\text { ex TEC } \S 228)\end{array}$ \\
\hline
\end{tabular}


Table I. Continued

\begin{tabular}{lll}
\hline Content of Rule & Time Rule & Article \\
\hline Legislative proposals & Timing & $\begin{array}{l}\text { TFEU } \$ 293 / 2 \\
(\text { ex TEC } \S 250 / 2)\end{array}$ \\
$\begin{array}{l}\text { b) In the Rules of Procedure } \\
\text { Content of Rule }\end{array}$ & Rule \\
Work program & Time Rule & $\S 2$ \\
Meetings & Regularity & $\S 5$ \\
Written procedure & Regularity & $\S 12$ \\
Preparation of documents & Duration & $\S 23$ \\
Letters addressed to the & Sequence & Annex, Chapter 4
\end{tabular}

Commission

c) In the Implementing Rules ("Rules giving effect to the Rules of Procedure")

\begin{tabular}{lll} 
Content of Rule & Time Rule & Rule \\
Policy debate & Regularity & $2(1)$ \\
Agenda setting up & Timing & $6(3.1,3.2)$ \\
Agenda circulation & Timing & $6(4.1)$ \\
Agenda (continuing) & Timing, Sequence & $6(4.2)$ \\
Item Preparation & - & $6(5.1)$ \\
$\begin{array}{l}\text { Written procedure } \\
\text { (in general) }\end{array}$ & Timing & \\
$\begin{array}{l}\text { Expedited written procedure } \\
\text { Urgent written procedure }\end{array}$ & Timing & $12(4.1)$ \\
$\begin{array}{l}\text { Finalisation written procedure } \\
\text { 'Communication on a Council } \\
\text { position' written procedure }\end{array}$ & Timing & $12(4.3)$ \\
$\begin{array}{l}\text { Extension of time limits for } \\
\text { written procedures }\end{array}$ & Timing & $12(4.4)$ \\
$\begin{array}{l}\text { Adoption in Written Procedure } \\
\text { Exercise of powers under the } \\
\text { empowerment and delegation } \\
\text { procedures }\end{array}$ & Timing & $12(4.5)$ \\
$\begin{array}{l}\text { Decision information } \\
\text { Cooperation and coordination } \\
\text { between departments }\end{array}$ & Duration & $12(4.6)$ \\
$\begin{array}{l}\text { Formal interservice consultation } \\
\text { Alternatives to formal written } \\
\text { interservice consultation }\end{array}$ & Timing & $12(5.1)$ \\
\hline
\end{tabular}


Several points are noteworthy. First, in the Treaties (TEU/TFEU), apart from regulations on the term lengths of the Commission President and the Commissioners and the possible reallocation of responsibilities at any time, there are no time rules that relate explicitly to the internal functioning of the Commission, but only some time-related provisions governing the inter-institutional relations of the Commission (especially orders of process and time limits, sometimes to be set by the Commission, in cases of state aids' review, of state budget monitoring, or of member states' treaty violations). Likewise, the Commission's Rules of Procedure are largely silent when it comes to temporal rules, with the exception of the mention of the annual work programme and the weekly College meetings. However, the Rules of Procedure make frequent reference to the Implementing Rules. It is only in the latter that more detailed regulations are found. One focus here is the 'agenda building' for the College meetings, with time limits to propose items or hand in necessary documents. Second, there is an emphasis on the 'written procedure'. Here it is interesting to note that the SecretaryGeneral - with the agreement of the Commission President - can shorten the available time period for comments or objections. Also, 'At the request of a Member of the Commission, or where the Secretary-General finds that the draft text does not meet all the requirements concerning substance and form, the time limit [...] shall be extended by a period not exceeding that originally set' (Implementing Rules, Art. 12, Point 5.1). When it comes to interservice consultation on policy initiatives, the Implementing Rules are also quite brief in respect of time rules (paragraphs 23 (1), (4.2) and (5.2.)).

At least at first sight, time in the Commission may appear only lightly institutionalised. Few time rules are set at the highest level of formality - the Treaties; formal time rules appear not very detailed and dense; and, importantly, enforcement and sanctioning mechanisms are largely unspecified. However, for several reasons such a conclusion is misleading. First, as already noted above, many formal important time rules - at the level of the Treaties, in Interinstitutional Agreements and also in the Rules of Procedure of the other EU institutions concern different aspects of interinstitutional relations. As such they not only set the time 'rules of the game' governing relations amongst the EU institutions, but also affect the internal operation of the Commission. Second, there are many policy specific time rules that need to be followed, whether it concerns budgetary policy or, for example, the Commission's activities in the field of competition policy. Third, there exist well-developed temporal routines in the Commission and, in particular, a dense web of synchronised meeting timetables that govern its internal operation, but also external consultation, notably through the numerous advisory expert committees, and cooperation in implementation, notably through the comitology committees. Fourth, strategic planning and programming have rapidly gained in importance, further intensifying authoritative temporal structuring of the Commission's activities. Each of these points deserves some elaboration.

As regards, first, time rules governing interinstitutional relations that feed back into the Commission, they are numerous and can be found at different levels. In the 
Treaties, they concern, in particular, legislative procedures, notably TFEU Art. 294 and also procedures for Treaty amendments (TEU Art. 48). In Interinstitutional Agreements (IIAs), we find, for example, rules on regular meetings involving the President and or/the Vice-presidents of the Commission and the Conference of Presidents in the 2003 IIA on Better Law-making; on 'early' or 'immediate' information to be provided by the Commission in the 2005 Framework Agreement on European Parliament - Commission Relations; or on deadlines for the submission of Commission opinions in the 2007 Joint Declaration on Practical Arrangements for the Codecision Procedure ("The Commission shall, as a general rule, submit its opinion within three weeks of official receipt of the outcome of the European Parliament's vote and at the latest by the commencement of conciliation proceedings"; Article 33). Moreover, the rules of procedures of other EU institutions have implications for the temporal ordering of activities in the Commission, such as, for example, Rule 117 of the European Parliament's Rules of Procedure concerning questions for written answers to the Council or the Commission. It lays down that 'Questions which require an immediate answer but no detailed research (priority questions) shall be answered within three weeks of being forwarded to the institution concerned (...) Other questions (non-priority questions) shall be answered within six weeks of being forwarded to the institution concerned'.

A further important source of rules affecting organisational behaviour are policy-specific regulations. Of these, the Treaty rules governing decision-making on the multiannual financial framework (TFEU Article 312), the annual budget (TFEU Articles 313 to 316) and on the implementation and discharge of the budget (TFEU Articles 317 to 319) are the most important. The Treaty rules are complemented by the 2006 IIA on Budgetary Discipline and Sound Financial Management. As far as the annual budget is concerned, the Treaties contain a detailed timetable governing its preparation and adoption, which binds the Commission and other actors, although as Nugent (2010: 411) has observed in relation to the process prior to the coming into force of the Lisbon Treaty, it is worth making the general point that, as with all EU decision-making procedures, the formal rules (...) provided but a framework that in practice was fleshed-out and adapted by the budgetary actors in response to pressures, necessities, and convenience'. The preparation of the budget, an activity which, in some form, involves almost all parts of the Commission administration, financial programming and the implementation of the budget take place within a tight temporal grid that mobilises actors across the organisation.

Other policy areas also follow specific time-related policy-making rules that translate into more or less elaborate organisational schedules. An illustrative example is EU competition policy, encompassing state aid monitoring, antitrust and cartel policy, and merger control. In principle, we should expect considerable temporal discretion for the Commission in this area; after all, 'European competition policy is de facto a Commission policy. It is the Commission that determines what the policy is and how it is implemented on the ground. It is the Commission that identifies a breach of rules, undertakes the investigation and decides whether to 
take a formal decision. And it is the Commission that fines, and even establishes the level of the penalty' (Cini and McGowan 1998: 41). Yet, if one examines the rules setting out the different procedures, one finds that the latter are indeed governed by detailed timetables, established primarily through Council and Commission Regulations, but also best practice codes. A few examples may suffice. In state aid control, if the Commission decides to open a formal investigation procedure, 'The Commission shall as far as possible endeavour to adopt a decision within 18 months from the opening of the procedure (...) Once the time limit referred to (...) has expired, and should the Member State concerned so request, the Commission shall, within two months, take a decision on the basis of the information available to it' (Council Regulation (EC) No 659/1999, Article 7, Point 6). In antitrust and cartel policy, the Commission has restricted its own temporal discretion to some degree. Thus, in handling complaints, 'The Commission is under an obligation to decide on complaints within a reasonable time. What is a reasonable duration depends on the circumstances of each case and in particular its context, the various procedural steps followed by the Commission, the conduct of the parties in the course of the procedure, the complexity of the case and its importance for the various parties involved' (Article 60, Commission Notice on the handling of complaints by the Commission under Articles 81 and 82 of the EC Treaty, 2004/C 101/ 05). 'The Commission will in principle endeavour to inform complainants of the action that it proposes to take on a complaint within an indicative time frame of four months from the reception of the complaint' (Article 61). Tighter deadlines for Commission action apply in merger control. Thus, it has been noted that 'The fact that the EC decides on mergers within strict deadlines is a notable feature of the Merger Regulation, and one that should be praised' (Motta 2004: 36). Thus, the Commission enjoys little temporal discretion when dealing with merger cases.

Next to time rules laid down in the Treaties, Interinstitutional Agreements, Rules of Procedures, Implementing Rules and policy-specific procedural regulations, there are, as in any large bureaucracy, routinised timetables, notably as regards regular meetings at different levels and in different parts of the organisation. Dense scheduling has a mobilising and prioritising effect: actors arrange their activities with a view to the deadlines imposed by the grid of regular meetings. Of importance for the Commission administration as a whole are the meetings in preparation of the regular Wednesday meetings of the College of Commissioners, in which the Commissioners' cabinets play a special role. The following quotation gives a good impression of this coordinating machinery geared towards the Wednesday meetings of the Commissioners:

Each cabinet's coordinating role is governed by the timetable of the Commission's weekly meetings, normally held on Wednesdays. Issues requiring a Commission decision must be signalled at least nine days in advance of the relevant Commission meeting, usually at the chefs de cabinet meeting held at the beginning of the previous week. The Secretariat General circulates an updated outline agenda each week. Indicative longer-term timetables of the Commission are also circulated. They are 
designed to help prevent excessive bunching of major issues at particular meetings, to enable all and sundry to manage their own diaries and to set indicative timelines for ending routine coordination by authoritative decision-making (...) Substantive sectoral policy proposals are discussed at meetings of representatives of all Commissioners' cabinets, known as 'special chefs' meetings (...) During a normal week there are likely to be six or seven such cabinet meetings (...) Papers for these meetings have to be circulated 48 hours in advance (...) Coordination between the Commissioners' cabinets takes place within a tight time-scale and with firmly fixed procedures. The conclusions of special chefs meetings form the input of the Monday chefs de cabinets meeting... (Spence 2006: 67).

This carefully synchronised schedule is complemented by equally routinised meeting schedules within the different Directorates General.

The appearance of dense scheduling is further reinforced if we consider the numerous meetings of the approximately 1200 expert groups advising the European Commission in the preparation of its initiatives, some of which meet on a monthly basis. As Gornitzka and Sverdrup (2009: 733) have pointed out 'The large number and the strong growth of the use of expert groups in the European Commission contribute to making this mode of interaction a significant element of the European governance structure, and a routinised and rather standardised mode of consultation'. Equally, the Commission's role in the implementation of legislation is subject to dense scheduling, notably through the Comitology committees, of which 268 existed in 2011. They met 783 times in total in that year. The 14 committees active in the field of agriculture alone met 142 times (European Commission 2012). The most visible results of the committees' work were no fewer than 1868 'opinions' and 1625 'implementing acts' adopted in 2011 (ibid.). These high figures give a first indication of the extent to which the comitology committees' dense schedule of meetings affect the temporal ordering of activities in the Commission, as the meetings have to be prepared and followed up.

A further important device for setting, monitoring and enforcing the administrative clock is provided by strategic planning and programming (SPP) in the Commission, which is a cyclical exercise that affects the temporality of the organisation as a whole in two basic ways. First, the cycle of planning and programming follows a fixed timetable, which effectively sets deadlines for substantive inputs from throughout the organisation; second, and no less importantly, the various documents adopted contain detailed schedules for the delivery of Commission actions which serve as an important commitment device.

SPP is a complex process. Upon entering into office, the new Commission is expected to adopt five-year strategic objectives for the duration of its mandate. The strategic objectives inform the President's annual State of the European Union address, which, like the Annual Policy Strategy until 2009, 'defines priorities and strategic objectives for the following year' (http://ec.europa.eu/atwork/planningand-preparing/strategic-planning/index_en.htm). Following discussions with the Council and the European Parliament, the Commission adopts an Annual Work 
Programme, which contains an action plan and concrete 'deliverables'. On this basis, each Directorate-General, in turn, adopts its own Annual Management Plan. The latter is expected to 'set clear, specific, measurable and verifiable objectives for each activity as well as indicators for the monitoring and reporting on the progress made and the impact of the activities to the EU citizens' (http://ec.europa. eu/atwork/planning-and-preparing/strategic-planning/index_en.htm) and thus enable the management 'to plan, follow up and report on all the activities and resources of each directorate-general' (http://ec.europa.eu/atwork/synthesis/ index_en.htm). For day-to-day management, the annual plans are supplemented by a list of planned Commission initiatives, which is updated monthly. To conclude the annual cycle, each Directorate General must prepare an Annual Activity Report, in which it documents to what extent the annual management plans have been implemented. The main points of these reports are contained in a Synthesis Report submitted by the Commission to the Council and the EP.

Not only does the SPP process itself follow elaborate time rules; by setting out the Commission's priorities and initiatives publicly and well in advance, it serves as a very visible commitment device and establishes a timetable for the Commission's activities. But how authoritative is this timetable and where does authority to define and enforce it lie? As regards the first question, a Commission insider has noted that SPP, although elaborate,

cannot fully capture the more political and discretionary nature of the Commission's work. In particular, the requirement to conduct an IA [Impact Assessment] may prove cumbersome for political documents produced in response to new events or for a pressing political mandate (...) Moreover, the system is ill-suited for more confidential, diplomatic or trade negotiation documents. In practice, the risk exists that only the most easily planned items will be registered in the work programme while key, but unforeseen, political initiatives will not, thereby reducing the credibility and use of the instrument. The Commission has, therefore, become used to updating its work programme half-way through its implementation (Tholoniat 2009: 234).

As this quotation indicates, the Commission as a collective body certainly retains some necessary discretion; but empirical analysis suggests that SPP works quite effectively, both in translating political guidelines into concrete initiatives and in ensuring that planned initiatives are, in fact, undertaken (see Kassim et al. 2013).

\section{Actors' Time Budgets and Time Horizons}

In order to get a sense of the timescape of the Commission, our discussion has so far focused on time-centred rules and practices that govern planning and policymaking processes. They mobilise actors, influence their priorities and structure their calendars. Yet, the importance of such rules and practices is, in part, dependent on actors' individual time budgets and the time horizons that they are likely to adopt. At the level of top policy-makers, the period of office is critical in this 
respect. For example, a Commissioner with a time budget of a five-year mandate, but with no prospect of returning to his portfolio, is likely to operate with a different time horizon than one who is fairly confident of returning to her post in a new Commission. A Director-General who takes over a portfolio for a predetermined time, as is now the case, is likely to adopt a shorter time horizon than one whose term of office is, in principle, open-ended, as used to be the case.

The official length of a Commissioner's mandate is 5 years (TEU Art. 17/3). Responsibilities can be reallocated amongst Commissioners at any time (TFEU Art. 248). A Commissioner 'shall resign if the President so requests' (TEU Art. 17/ 6 ), and the whole body shall resign in the case of a motion of censure by the European Parliament (TEU Art. 17/8). ${ }^{1}$ There is the chance of a considerable time lag between the nomination of the President of the Commission and the confirmation of the College. Thus, in 2004, five months passed between Barroso's nomination by the European Council on 29 June (and his approval by the European Parliament on 22 July) and the European Parliament's approval of the whole College on 18 November. In 2009-10, there was a gap of seven months between Barroso's nomination on 9 July 2009 (approved by the European Parliament on 16 September) and parliamentary approval of the whole College on 9 February 2010. Such a headstart for the President of the Commission matters because it allows him a window of opportunity to shape the new Commission's priorities well before the new Commissioners are in place. Thus, already on 3 September 2009, Barroso sent his 'Political guidelines for the next Commission' to the European Parliament, which then formed the basis for the Commission's later work programme.

What is the time budget available to members of the Commission? Between 1958 and the beginning of the Barroso II Commission in February 2010, the average tenure of a Commission President was 4.67 years. The average tenure of Commissioners - of whom there were 121 in total - was 5.82 years; their average tenure in the same portfolio was 4.58 years. $^{2}$ Of the total population of Commissioners, 58 per cent served for one full term or less; 30 per cent for two full or partial terms; and 12 per cent for more than two terms. As Figure 1 shows, tenures have not changed greatly over time, if we disregard the first generation of Commissioners. Those who left office in the 1960s had, on average, served 6.6 years, while those who left office in the 2000s had served one year less on average, i.e. 5.6 years. The gap is more pronounced if we regard the time Commissioners served in the same portfolio. In the 1960s, Commissioners left office or changed responsibilities after having served 6.5 years in one portfolio, while in the 2000s Commissioners served only 4.4 years in the same portfolio.

Amongst those with more than one term, 53 per cent had to change their portfolio once or even twice. If we consider the reappointment rates of Commissioners (excluding Presidents) at the turning point of two Commissions, between 1958 and 2010, 48 per cent were re-appointed, but only 22 per cent to the same portfolio. The re-appointment rate declines in the long run, but it has been quite high again at the shift from Barroso I to Barroso II, with 13 out of 26 


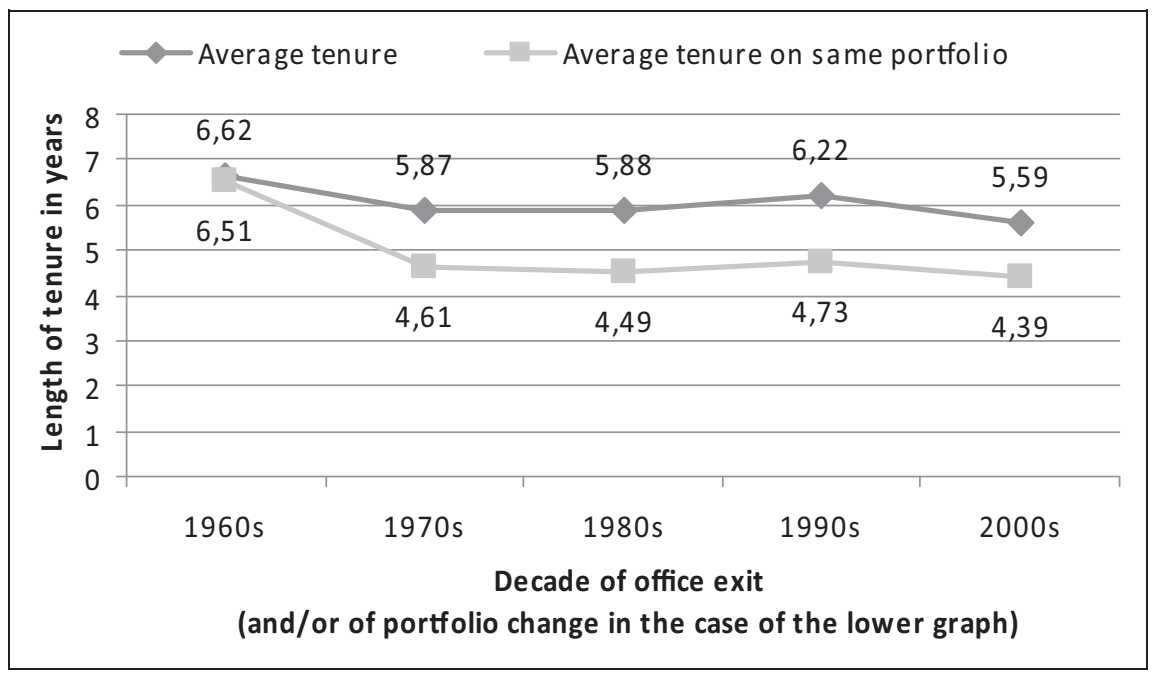

Figure I. Average tenure of Commissioners (according to the decade of office exit/portfolio change).

Own calculations.

Commissioners re-appointed. Yet, with the exception of Catherine Ashton, who was appointed as High Representative on 1 December 2009 and was re-appointed with the rest of the Commission on 9 February 2010, all Commissioners changed portfolios.

It is instructive to compare the length of time of Commissioners in charge of a portfolio with that of top officials. The Commission administration is mainly composed of permanent officials; but, since the late 1990s, rules relating to the rotation of senior staff have contributed to a decline in the average tenure of top officials. Based on a decision taken in 1999 by the Prodi Commission, 'The general rule is that all senior officials serve a minimum of two years in any function and a maximum of five years. At the end of this five-year period, the official would be due for mobility to another function. Exceptionally, a senior official's assignment in the current position could be extended for an additional and final period of two years. At the end of that period, the official would be reassigned to another function' (COM Decision 25 Oct 2004).

This decision has had appreciable consequences in that the average tenure of Directors-General in charge of one portfolio has declined substantially over time. As Figure 2 shows, the average duration for which a Director-General had been in charge of the same portfolio before he changed responsibilities or left the Commission was 7.2 years in the 1980s, 5.51 years in the 1990s, and 4.88 years between 2000 and 2009. ${ }^{3}$ By September 2010, no Director-General had been in post for more than 5 years. The time budget of the top officials in the 


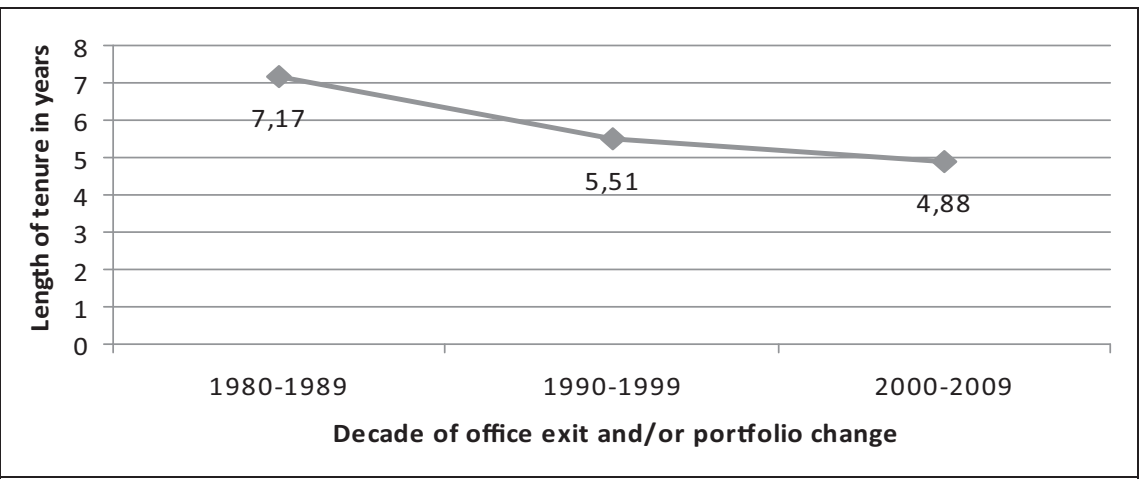

Figure 2. Average tenure of Directors-General on one portfolio (according to the decade of leaving portfolio).

Own calculations: Data basis: all Directors General of policy-focused DGs (no internal services/ DGs, except the Secretariat General) who left their office between 1980 and 3I December 2009 $(n=103)$.

Directorates-General has, thus, come to approximate that of their political 'principals', i.e. the Commissioners. In the present context, it is especially relevant to note that the sole exception to the rule of rotation amongst top officials has been the Secretary-General of the Commission, Catherine Day, who has been in office since 2005.

Importantly, Commissioners' and Directors-General's tenures coincide in many cases. Thus, by the beginning of September 2010, of the 26 Director-Generals in charge of policy-related portfolios, 13 had come into office since February 2010, when the new Commission took power, and a further six were due for replacement before the end of the year.

The impression of limited and coinciding time budgets for the key actors within the Commission is further reinforced when we examine Commissioners' cabinets, whose centrality in the Commission policy process is well-documented (see most recently Wille (2013), pp. 97-118, with further references). All cabinets members are appointed by the relevant Commissioner; the cabinets are composed of both permanent Commission officials seconded to the cabinet and 'outsiders on secondment from national administrations or the private sector. The latter tend to spend an average of two to three years in a cabinet' (Spence 2006: 65). As Spence (70) highlights, this temporal limitation may come at a price: members of cabinets 'are reliant on Commissioners for their job and this might conceivably limit their willingness to give critical advice (...) it is clearly difficult for cabinets to strike a successful balance between developing a long-term strategy and responding to current and pressing issues'.

More generally, Georgakakis (2012), in his recent work on the personnel of the EU institutions, has highlighted the connection between officials time 
budgets - notably the distinction between permanent and seconded staff - and their time horizons:

du cóté du pôle des intermittents, la temporalité sur laquelle se fondent des façons de penser et d'agir est celle des agendas politiques et communicationnels nationaux, voire celle des plus ou moins brusques variations économiques et financières (...) La temporalité est differente sur le pôle des permanents de l'UE. Elle est celle, plus lonque, de la construction européenne, selon une définition plus volontiers hiérocratique que politique qui prédispose à juger les choses à l'aune d'un avenir de moyen et long terme (ibid.: 324).

\section{Power through Time}

The preceding sections have described key elements of the Commission's timescape, with an emphasis on time rules and practices at the levels of policyrelated processes, and time budgets and time horizons of top staff. What do these observations tell us about the distribution of power within the Commission? In particular, what does a time-centred analysis reveal about the degree of bureaucratic autonomy from politics and the degree of centralisation within the organisation? In considering these questions, we return to the three basic assumptions about the link between time and power introduced at the outset, which highlighted the importance of differentials in time budgets and time horizons; actors' relative temporal discretion; and the distinction between time-setters and time-takers.

The central point to note is that a time-centred analysis chimes with recent organisational analyses of the Commission, with their emphasis on the strengthening of political office holders and the growing power of central coordination units (Kassim et al. 2013; Wille 2013). Time rules and practices within the Commission both reflect these general trends and appear to have acted as a stimulus behind them. Thus, Kassim (2006: 85) has highlighted how the management of the elaborate timetables that govern strategic planning and programming have allowed the Commission to 'take a more directive approach'. This point is underscored by Tholoniat (2009: 232), who has emphasised the extent to which the SecretariatGeneral acts as a time-setter and time-monitor in SPP:

The combination of SPP-IA [Impact Assessment] tools may have contributed to the (re)centralization, consistency and collegiality of the internal decision-making process. The Secretariat General plays a key role in the operation of these instruments and it has contributed to spreading a culture of 'upstream co-ordination', inviting services to plan ahead and revisit the timetable of their initiatives in the light of the overall priorities of the College. It also plays an increasingly pivotal role in steering and screening new policy initiatives, with the possibility of being associated with, or to take over the leadership for, essential files. 
At least three developments interact here: hierarchisation of opportunities for timesetting; the restriction of temporal discretion at lower levels of the organisation as a result of authoritative advance scheduling; and, as Bauer (2008) suggests, a limitation in the time budgets for policy-related work available to administrators lower down the hierarchy. The impression of a strong temporal subtext to politicisation and centralisation in the Commission is reinforced if we take into account that many of the formal time rules that the Commission follows are self-imposed through the Implementing Rules, which fall under the responsibility of the Secretariat-General, and also the Commission's Manual of Operating Procedures, the content of which is likewise managed by the Secretariat-General.

The implications of changes in the time budgets and time horizons of the top policy-makers are more ambiguous. The first important trend to note is the decrease in their overall time budget, as expressed by the time Commissioners stay in the same portfolio. Despite the fact that the Maastricht Treaty lengthened the period of office of Commissioners from four to five years so as to synchronise the Commission with the European Parliament, the length of time for which Commissioners retain responsibility for one portfolio has decreased over time, though this decrease is, in part, due to the shortened Delors Commission of January 1993 to January 1995. Given that even in the event of reappointment, a Commissioner's chances of retaining his portfolio are, according to present practice, very slim, this portfolio-related time budget is also likely to have a key influence on the time horizon a Commissioner adopts in the temporal ordering of his activities over his period of office.

What incentives do Commissioners have to look beyond the likely end of their period of office when it comes to timing their initiatives, notably as regards the initiation of legislation requiring the agreement of the European Parliament and the Council? Figures 3 and 4 show the temporal distribution of the initiation of legislative acts - directives, regulations and decisions - over the course of the Prodi and Barroso I Commissions. A number of observations are apparent. We can see, for example., that the last quarter of the year is typically particularly busy in terms of the initiation of legislation, a phenomenon that is likely to reflect both the springing into gear of the Commission administration after the summer break and a desire to fulfil commitments made in the Annual Work Programme and the Directorates-General's annual management plans. More pertinently in the present context, it is noticeable that there is neither a marked falling off of activities towards the end of a Commission's tenure nor is there unequivocal evidence of a pronounced rush to get initiatives under way as the Commission's mandate is about to expire (for a fuller discussion of legislative cycles in the EU see Kovats 2012).

How might the time horizons of Commissioners' influence this distributional pattern? To answer this question, a brief look at the situation in national parliamentary systems may be instructive. Here, we can typically observe a flurry of legislative activity towards the end of the government's term of office, as the incumbent majority uses legislation to cement its own priorities and preferences beyond the election date. There is also evidence of electoral business cycles, with electorally 


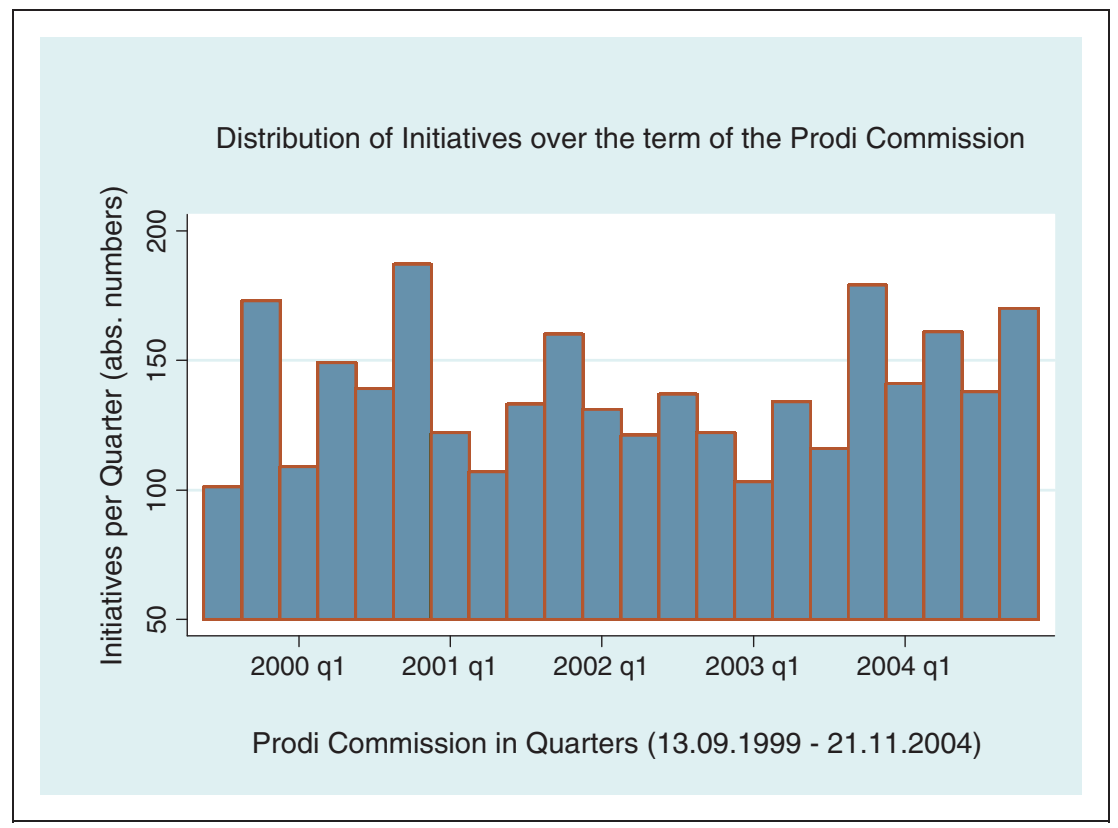

Figure 3. Temporal distribution of legislative initiatives in the Prodi Commission Note: How to read the Graphs: The bars represent the absolute number of initiatives in one quarter of a year. Example: in quarter one of the year 2000 (2000 ql) the Prodi Commission initiated 109 binding legislative acts (Directives, Regulations, Decisions). In quarter three of the year 2002, the figure was 133.

motivated timing of initiatives designed to curry favour with the governing parties' potential voters (Martin 2004). In nearly all parliamentary democracies, the discontinuity principle applies, so that legislation still pending in parliament at the time of its dissolution is abandoned. Government bills must, therefore, be submitted early enough to allow sufficient time for the conclusion of the parliamentary legislative process.

In the case of the Commission, the situation is more complex. Unlike a government, the Commission does not, of course, run for popular re-election, though the Commission President and individual Commissioners may well be running the equivalent of 're-election campaigns' to secure the support of member states. But whatever a Commissioner's individual achievements, his chances of returning to the same portfolio are virtually non-existent. This consideration might be taken to suggest that he should time his legislative initiatives early enough so as to be able to see them through whilst still in office. There are, however, two crucial features of the EU legislative process that incentivise Commissioners to keep on initiating legislation until the end of their term of office. First, the discontinuity principle does not apply in the European Parliament, as legislation still pending is routinely 


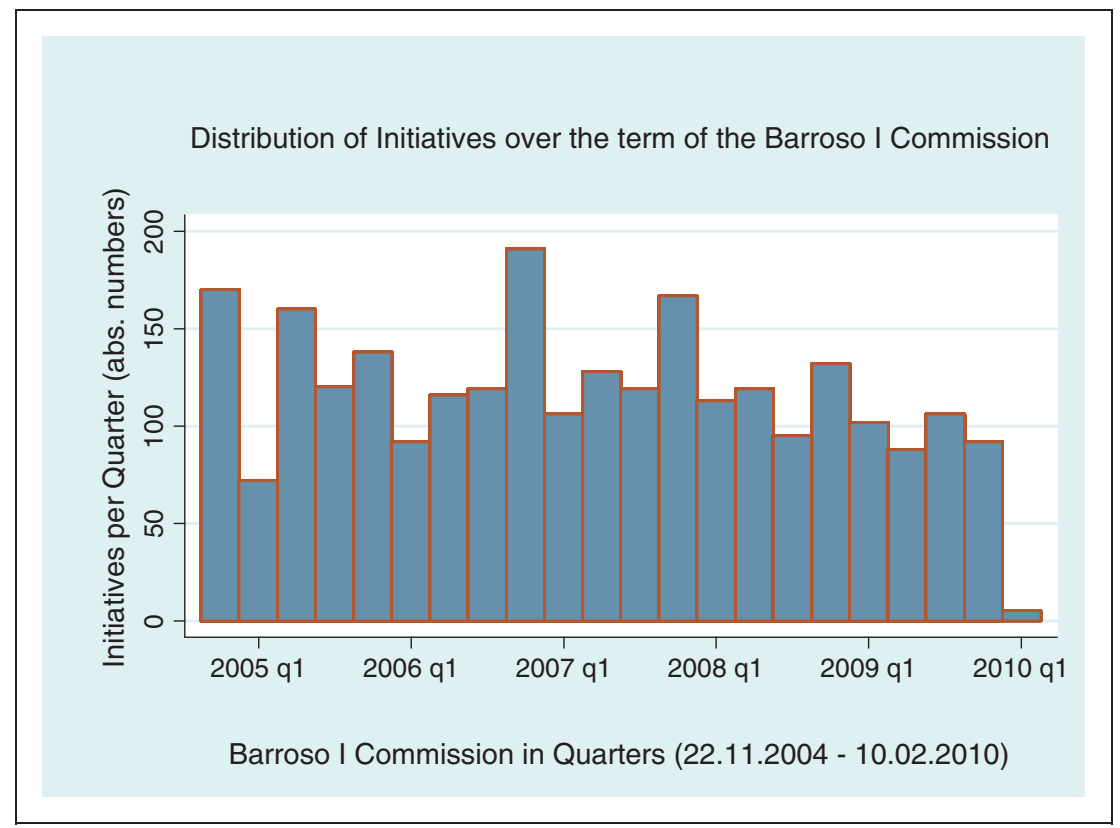

Figure 4. Temporal distribution of legislative initiatives in the Barroso I Commission

carried over into the next parliament (Kovats 2009). Second, as there is no majority-opposition dynamic within the European Parliament, eventual approval of a legislative initiative by the European Parliament and the Council without major modifications is no more or less likely before an election than afterwards. Thus, it is rational for Commissioners to keep initiating legislation until the end of their term of office.

If we turn from the political to the administrative level, we have noted above that the policy-related time budgets of Directors-General have shrunk significantly over the years as their tenures in one portfolio have shortened. Their budget is now very similar to that of Commissioners and members of cabinets and they do (no longer) possess a power advantage associated with a longer tenure that would encourage them to take 'the longer view'. Moreover, in many cases, time budgets coincide, as the appointment of new, and the rotation of existing, DirectorsGeneral takes place close to the time when Commissioners come into office.

\section{Concluding Remarks}

One should not overstate the extent to which a large and complex organisation such as the Commission can be made to 'tick' according to centrally set and monitored clocks and to which temporal discretion at lower levels in the organisation can be restricted. First, as was noted above, many of the temporal requirements 
governing activity in the Commission are not self-imposed, but arise from its interaction with other institutions, notably the European Parliament and the Council. Thus, the Commission is often as much a time-taker as it is a time-setter, which it notably does through its right of legislative initiative. This implies limitations on central political steering in the Commission through internally-set timetables.

Second, the Commission continues to be a decidedly heterotemporal organisation. Although there are overarching rhythms, for example, the budgetary process, and elaborate decision-making and planning schedules, the steady extension of the acquis has meant that an ever increasing range of policies runs, at least in part, according to policy-specific timetables. There is, therefore, considerable differentiation of organisational time. This observation means that there are clear limitations to centralised steering by the Secretariat-General, with the latter often operating more as a "time manager" involved in synchronising activities than a 'time-setter' able to impose timetables.

Third, there is power in temporal routines. Much of what goes on in the Commission is structured temporally by entrenched timetables, whether it concerns the elaborate schedule of meetings building up to the weekly gathering of the Commissioners, comitology meetings or meetings of expert groups. Such organisational routines constitute the basic rhythm of everyday bureaucratic life and they provide a shield at lower levels of the organisation against hierarchical intervention.

These caveats notwithstanding, there is definite temporal subtext to power shifts within the Commission, from the administrative to the political level, and from line units to central coordination bodies. Administrators at the levels of heads of units are said to have 'less time' for policy work than in the past (Bauer 2008); the time budgets of Directors-General are declining relative to Commissioners and cabinets; and the time horizons of senior officials cannot be assumed to systematically extend beyond those of Commissioners. Time setting and time monitoring within the organisation rely on hierarchy, and time management by the Secretariat-General has become an important device for steering the administration. As a result, temporal discretion lower down the organisation has decreased.

\section{Notes}

1. A special case is the new High Representative and Commissioner for external relations: 'The European Council, acting by a qualified majority, with the agreement of the President of the Commission, shall appoint [him]. The European Council may end his term of office by the same procedure' (TEU Art. 18/1). He 'shall resign, in accordance with the procedure set out in Article 18(1), if the President so requests' (TEU Art 17/6). In the case of a motion of censure, he 'shall resign from the duties that he carries out in the Commission' (Art. 17/8).

2. Included in the data are all Commissioners in office since 1958 and who had left the Commission by 9 February 2010, i.e. at the switch from Barroso I to Barroso II; they exclude Commissioners currently still in office. Commissioners who were also President of the Commission (before or after it) and Commissioners who held office twice, but with interruption, were coded as two individual people. The Commissions under Presidents 
Malfatti and Mansholt are treated as one commission (one single term). The caretaker status of the Santer Commission between its resignation and the interim appointment of the next Prodi Commission (16.03.1999-15.09.1999) is not treated separately. With regard to calculations on tenures 'on one portfolio', portfolios of a Commissioner in different (successive) Commissions are treated as the same, when all or at least a substantial part (policy field) of his former portfolio remained under his responsibility.

3. Data drawn from the EUROGUIDE annuals; so only on an annual basis - no exact dates of office entry and office exit; when one is mentioned as Director-General in the 2005 Euroguide, it has been assumed that he was in office the whole year; when there was another name on the same portfolio in the Euroguide one year later, it has been assumed that the change took place the 1 January 2006 - this does not pose a problem as we do not look at individual tenures, but only at averages - and averages just depend on how many different people held an office over a certain period of time. As there were no Euroguides in 1995 and 1997, we took the data from the year before, assuming that the office holder from the preceding year was still in office. For Director-Generals who started office before the first Euroguide 1977 we asked the Commission for the year of their entry. For those listed in the 2009 Euroguide we checked whether they had left office in late 2009.

\section{References}

Ancona D, et al. (2001) Taking time to integrate temporal research. Academy of Management Review 26(4): 512-529.

Bauer MW (2008) Diffuse anxieties, deprived entrepreneurs: commission reform and middle management. Journal of European Public Policy 15(5): 691-707.

Bluedorn AC and Denhardt RB (1988) Time and organizations. Journal of Management 14(2): 299-320.

Cini M and McGowan L (1998) Competition Policy in the European Union. Houndmills: Palgrave.

Ekengren M (1996) The Europeanization of state administration: adding the time dimension. Cooperation and Conflict 31(4): 387-415.

Ekengren M (2002) The Time of European Governance. Manchester: Manchester UP.

European Commission (2004) Compilation Document on Senior Officials Policy. http:// ec.europa.eu/civil_service/docs/official_policy_en.pdf

European Commission (2012) Report of the Commission on the Working of Committees 2011. COM2012 (685 final).

European Commission-DG Competition (2010) EU Competition Law: Rules Applicable to Merger Control. http://ec.europa.eu/competition/mergers/legislation/merger_ compilation.pdf.

Georgakakis D (2012) Le champ de l'Eurocratie: nouvelle carte, nouveaux horizons, in idem (ed.) Le champ de l'Eurocratie, Paris: Economica, 309-327.

Gornitzka A and Sverdrup U (2009) Who consults? the configuration of expert groups in the European union'. West European Politics 31(4): 725-750.

Kassim H (2006) The Secretariat General of the European Commission, in S Spence with G Edwards (eds.) The European Commission, $3^{\text {rd }}$ ed., London: John Harper Publishing, 75-94.

Kassim H, et al. (2013) The European Commission of the Twenty-First Century. Oxford: Oxford University Press. 
Kovats L (2009) Do elections set the pace? a quantitative assessment of the timing of European legislation'. Journal of European Public Policy 16(2): 239-255.

Luhmann N (1971) 'Die Knappheit der Zeit und die Vordringlichkeit des Befristeten', in idem, Politische Planung, Opladen: Westdeutscher Verlag.

Martin LM (2004) 'The government agenda in parliamentary democracies'. American Journal of Political Science 48(3): 445-461.

Meyer-Sahling JH and Goetz KH (2009) 'The EU Timescape: From Notion to Research Agenda'. Journal of European Public Policy 16(2): 325-336.

Motta M (2004) Competition Policy: Theory and Practice. Cambridge: Cambridge University Press.

Nugent N (2010) The Government and Politics of the European Union, 7th edition. Basingstoke: Palgrave.

Pollitt C (2008) Time, Policy, Management: Governing with the Past. Oxford: OUP.

Scharpf FW (1997) Games Real Actors Play: Actor-Centered Institutionalism in Policy Research. Boulder: Westview Press.

Simsa R (1996) Wem gehört die Zeit? Hierarchie und Zeit in Gesellschaft und Organisationen. Frankfurt a. M: Campus.

Spence D (2006) 'The President, the College and the cabinets', in idem with G. Edwards (eds.) The European Commission. $3^{\text {rd }}$ edition. London: John Harper Publishing, 24-74.

Tholoniat L (2009) The temporal constitution of the European Commission: a timely investigation. Journal of European Public Policy 16(2): 221-238.

Wille A (2013) The Normalization of the European Commission: Politics and Bureaucracy in the EU Executive. Oxford: OUP.

Klaus H. Goetz holds the Chair in Political Systems and European Integration at the University of Munich. He previously taught at LSE and the University of Potsdam. He specialises in comparative government, public policy and public administration. He currently works on two research projects funded by the German Research Foundation on staggered membership renewal in second chambers and on budgeting in international administrations, respectively (see www. politicaltime.eu). He has been co-editor of West European Politics since 2000. 